\title{
SYNOD NEWS
}

\section{THE GENERAL SYNOD OF THE CHURCH OF IRELAND}

\author{
MICHAEL DAVEY
}

Five bills were brought before the Synod for consideration this year. Two of them were liturgical bills which, under the special procedures relating to such matters, require a two thirds majority at the first, second and third reading stages.

Bill number 1 provided for the use in churches of The Revised Common Lectionary. with introduction and additional canticles. It included a schedule setting out the readings. One amendment, removing the Song of Moses and Miriam from the Schedule, was successfully proposed. Subject to this amendment the Bill received the required majority and was declared passed.

Bill number 2, also dealing with the Lectionary, enabled the provisions concerning detailed changes to the number and order of readings from Scripture to apply in churches and chapels where the Lectionary is in use. It too was passed with the required majorities.

The third bill, presented at the request of the Pensions Board, dealt with episcopal pensions. It increased provision for retired bishops and widows of bishops in line with increases approved for serving bishops. These increases demonstrated the continuing and successful efforts of the Church of Ireland Pensions Board and the Representative Church Body to bring clergy pensions up from their previous low level. This bill was passed without opposition.

Bill number 4 sought to provide for flexibility in the deployment of some stipendiary clergy. The general approach is to assume that clergy, if not serving in the auxiliary ministry, are in the full time deployment of the Church. The Regulations with regard to approved stipends make a similar assumption. The proposed new rules were to permit deployment on a part-time basis, in posts certified as suitable by the Bishop and the Diocesan Council, of a minister who has held ecclesiastical office for not less than three years and who is not in receipt of a pension in respect of his service in the ordained ministry. Such ministers would be serving under licence from the Bishop and subject to the Bishop's direction and would not hold ecclesiastical office while in part-time employment. Their rights would be protected by a requirement for the Bishop, before making any deployment, to ensure the availability of appropriate financial provision. The Bishop would also have to provide written terms covering the duties and rates of remuneration applicable to such a minister. Finally, there would be a review of the deployment after a period of a year and thereafter every three years. This bill was duly passed.

The final bill was to amend Chapters III and V of the Constitution which deal with Parishes and Parochial Organisations. The intention of the bill was to abolish one of the forms of qualification for registration as a vestryman, namely that of property ownership. There were previously three ways of qualifying for registration, by residence, by accustomed attendance, or by ownership of property of a clear yearly value of ten pounds. Following the passing of the bill the nature of these qualifications has been reduced to two, those of residence and accustomed attendance.

The 1999 legislative programme was largely uncontroversial. It provoked little by way of debate. The main interest for synod members, and for the public at large. was in the debate which surrounded three motions attached to the report of a Sectarianism Working Group which had been set up by the General Synod in 1997. The group had been required to conduct an examination of the Church of Ireland itself with a view to 
seeing whether it might, albeit unwittingly, be guilty of sectarianism itself. The resolutions presented, while not amounting to legislation, would give, if passed, an indication of the collective mind of the General Synod and thereby carry a considerable weight of moral authority. The first resolution, dealing with flags, read as follows:

'The General Synod of the Church of Ireland recognises that from time to time confusion and controversy have attended the flying of flags on church buildings or within the grounds of church buildings. This Synod therefore resolves that the only flags specifically authorised to be flown on church buildings or within the church grounds of the Church of Ireland are the cross of St. Patrick or, alternatively, the flag of the Anglican Communion bearing the emblem of the Compassrose. Such flags are authorised to be flown only on Holy Days and during the Octaves of Christmas, Easter, the Ascension of Our Lord and Pentecost, and on any other such day as may be recognised locally as the Dedication Day of the particular church building. Any other flag flown at any other time is not specifically authorised by this Church.'

This resolution was passed.

The second resolution, dealing with the historic formularies of the church, read as follows:

'The Church of Ireland is part of the one, holy, catholic, and apostolic Church, worshipping the one true God, Father, Son and Holy Spirit. It professes the faith uniquely revealed in the Holy Scriptures and set forth in the catholic creeds; which faith the Church is called upon to proclaim afresh in each generation. Led by the Holy Spirit, it has borne witness to Christian truth in its historic formularies, the Thirty-nine Articles of Religion, the Book of Common Prayer, the Orderings of Bishops, Priests and Deacons and the Declaration prefixed to the Statutes of the Church of Ireland (1870).

These historic formularies are a definition of the faith as proclaimed by the Church of Ireland, and thus form an important part of the inheritance through which this Church has been formed in its faith and witness to this day. The formularies that have been passed on are part of a living tradition that today must face new challenges and grasp fresh opportunities.

Historic documents often stem from periods of deep separation between Christian Churches. Whilst, in spite of a real degree of convergence, distinct differences remain, negative statements towards other Christians should not be seen as representing the spirit of this Church today.

The Church of Ireland affirms all in its tradition that witnesses to the truth of the Gospel. It regrets that words written in another age and in a different context should be used in a manner hurtful to or antagonistic towards other Christians. The Church of Ireland seeks the visible unity of the Church. In working towards that goal this Church is committed to reaching out towards other Churches in a spirit of humility and love, that together all Christians may grow towards unity in life and mission to the glory of God.'

This resolution was passed.

The third resolution dealing with events at Drumcree Church read as follows:

'This Synod fully endorses the efforts of the Archbishop of Armagh, the Diocese of Armagh and the Standing Committee of the General Synod of the Church of Ireland in their attempts to resolve the crisis at Drumcree. It calls upon the Rector and the Select Vestry of Drumcree to endorse the pledges called for by the Archbishop of Armagh in respect of the conduct of those attending the annualparade of ledges of the Orange Order to Drumcree Parish Church. The pledges are as follows: 
* The avoidance of any action before or after the service which diminishes the sanctity of that worship.

* Obedience to the law of the land before and after the service.

* Respect for the integrity of the Church of Ireland by word and action and the avoidance of the use of all church property or its environs in any civil protest following the service.

This Synod further requests that should the Orange Lodges of the Portadown District decline to adhere to the pledges required by the Archbishop of Armagh. the invitation, established by custom, to the Lodges to attend morning service be withdrawn by the Rector and Select Vestry of Drumcree.'

This resolution was passed subject only to an amendment that the terms of the resolution should be communicated to the Rector and Seclect Vestry of Drumcree.

There were also three liturgical resolutions brought in under the special bill procedure whereby the resolutions constitute the first readings of bills to be proposed in the year 2000 . These resolutions, which were all passed by the necessary two thirds majority, represent the first steps in reconstructing the Prayer Book. a major task which will take until the year 2004. It is intended that this new book will contain both traditional Book of Common Prayer services and those of the Alternative Prayer Book. Some degree of alteration or amendment is planned by the Liturgical Advisory Committee which is sponsoring the legislation. No doubt the members of Synod will have ideas of their own, either to restrain the Committee members from making their amendments or to encourage them to go further, or, perhaps, both. The Committee's current proposals cover the following matters, namely

The Order for Morning Prayer

The Order for Evening Prayer

The Litany

The Appendix containing Alternative Forms of Evening Prayer

An Order for Morning and Evening Prayer

The Litany in contemporary language

A Late Evening Office

Weekday Intercessions and Thanksgivings

A Service of the Word for occasional use.

This list should provide plenty of material for amendment and debate.

Note. Reports in respect of recent and forthcoming meetings of Synods in England and Scotland, and of the Governing Body of the Church in Wales, will appear in the next issue. Ed. 